\title{
Cooperation in Times of COVID-19: Realizing the Right to Health in Developing
}

\section{Countries}

Key Words: cooperation, right to health, local NGOs, international organizations, weak states, COVID-19

\begin{abstract}
In the context of the Coronavirus pandemic, even strong states with considerable capacities, resources and infrastructure have now realized how difficult it is to guarantee the right to health for all its citizens. For low-income and weak states, the spread of COVID-19 intensifies many problems in health care systems and wider societies. In this forum article, we discuss the international duty to cooperate in the realization of social rights, like the right to health, as stipulated in the International Covenant on Economic, Social and Cultural Rights. We argue that multilevel actor partnerships, in which international organizations, national governments and local non-state actors pool their resources, can compensate, at least temporarily, the lack of state capacities and assume state-like functions in realizing the right to health. Local actors assume special responsibilities in these partnerships: They provide health care services to particularly vulnerable groups und can convey information on context-specific problems of rights-holders to the national government and international organizations. Drawing on varying examples, such as the Ebola outbreaks in Sub-Saharan Africa and the efforts of Gavi, the Vaccine Alliance, we discuss the potentials of multilevel actor partnerships in realizing the right to health and managing certain norm collisions at the same time. We also address the critical issue of their sustainability, especially after international partners withdraw. Our aim is to raise awareness for the obligation of more capable states to cooperate in order to address the health situation of vulnerable population groups in weak states during the current Covid-19 pandemic.
\end{abstract}

\section{Zusammenfassung}

Im Kontext der Corona-Pandemie wird deutlich, wie schwer es selbst starken Staaten in Europa mit erheblichen Kapazitäten, Ressourcen und Infrastruktur fällt, das Recht auf Gesundheit für alle Staatsbürger zu garantieren. Für Entwicklungsländer und schwache Staaten intensiviert die Verbreitung von COVID-19 viele Probleme in der Gesundheitsversorgung und der Gesellschaft. In diesem Beitrag diskutieren wir die in menschenrechtlichen Vereinbarungen, beispielsweise dem Sozialpakt, verankerte Kooperationspflicht von Vertragsstaaten zur Umsetzung sozialer Rechte, wie das Recht auf Gesundheit. Wir argumentieren, dass Mehrebenen-Akteurspartnerschaften, in denen internationale Organisationen, nationale Regierungen und lokale nichtstaatliche Akteure ihre jeweiligen Ressourcen bündeln, fehlende staatliche Kapazitäten zumindest temporär kompensieren können. Neben internationalen Organisationen, wie der Weltgesundheitsorganisation, haben lokale Akteure eine besondere Aufgabe in diesen Partnerschaften: Sie stellen Gesundheitsdienstleistungen für besonders verletzliche Gruppen bereit und können Informationen über Probleme und Bedürfnisse von Menschen in informellen Siedlungen oder abgelegenen ländlichen Gebieten an die nationale Regierung und internationale Organisationen zurückspiegeln. Anhand verschiedener Beispiele, wie den Ebola-Ausbrüchen in SubSahara Afrika und den Bemühungen der Impfallianz GAVI, diskutieren wir die Potentiale von Mehrebenen-Akteurspartnerschaften, aber auch die Frage ihrer Nachhaltigkeit. Unser Ziel ist es, auf die Kooperationspflicht ressourcenstärkerer Staaten hinsichtlich der Gewährleistung des Rechts auf Gesundheit in schwachen Staaten während der Covid-19 Pandemie aufmerksam zu machen. 


\section{Introduction}

COVID-19 is not only a global health threat but also a threat intensifier. The spread of the virus exacerbates already existing inequalities between countries and within societies. Like climate change, it leads to compound injustice (Shue 2014). This means, those who are already disadvantaged, in terms of education, access to health care, social security and employment opportunities, are most adversely hit by the severe consequences of the Pandemic. This is true in developed and in developing economies. Recent studies demonstrate that in the USA and in the UK, for instance, belonging to certain racial and ethnic groups is associated with a higher risk of being infected with and a higher likelihood of dying from COVID-19 (PHE 2020; CDC 2020). Due to underlying social determinants, such as healthcare access, educational, income and wealth gaps, as well as occupation in work settings with increased exposure to the virus and less possibilities to work from home, the virus intensifies situations of inequality and injustice (CDC 2020).

In many developing countries and weak state contexts, where governments lack the capacities to provide security, the rule of law, legitimacy or welfare services (Tyagi 2012), the effects of Coronavirus are even more devastating. In slums, townships and favelas throughout Asia, Africa and Latin America there is hardly any space for social distancing, hygienic conditions are difficult, and communities lack access to clean water to wash their hands or appropriate sanitation facilities. Without a functioning welfare state or the instalment of essential social services, vulnerable groups are not provided with basic health care services in case of a Coronavirus infection. Shortcomings in testing and data availability make it impossible to understand the extent of the health crisis in many African countries, including South Africa, where infection numbers are rising dramatically (Harding 2020). All over the developing world, oxygen supply, ventilators and qualified medical personnel are lacking. To compensate for missing medical staff, the Peruvian government, for instance, has now invited Venezuelan health workers, who have fled their home country, to support the health system in Peru without validating their degree (BBC 2020).

Governmental responses to COVID-19, like rigorous national lockdown policies, constitute a major disruption to existing livelihood strategies. With a significant amount of economic activities taking place in the informal working sector, there are no viable alternatives for day labourers, local market sellers or farm helpers to make a living, and lockdown can lead to social 
unrest or even violence. For example, India's government just gave four hours' notice before enforcing a rigorous lockdown that immediately halted all economic activity and prohibited any movement creating disproportional negative effects on those who are already struggling for survival (Ghosh 2020). In many states all over the world, protests against lockdown measures turned violent; riots over food and aid distribution took place; and certain governments used the crisis to increase political repression and violence against civilians (ACLED 2020).

In this forum article, we will discuss how the right to health can be realized in the face of the COVID-19 pandemic and corresponding lockdown policies in developing countries. What can be done if the state government lacks the capacities to implement the right to health for all? Based on earlier research results on multi-level actor partnerships (Jenichen and Schapper 2017) and a number of examples, such as the Ebola crises in Sub-Saharan Africa or efforts for an equitable distribution of COVID-19 vaccines by Gavi, the Vaccine Alliance, this contribution focuses on the role of cooperation in social rights realization. We argue that innovative forms of cooperation are urgently needed as the pandemic has become a global problem that cannot be addressed with isolated or nationalist responses. Thus, we will discuss how international organizations (IOs), national governments and local civil society actors can cooperate to reach out to the most vulnerable populations groups, raise awareness to healthrelated issues, provide essential health care services and deal with specific norm collisions. These partnerships can, at least temporarily, compensate lacking state functions relating to the provision of social services. However, we also emphasize that, to be sustainable, they must not evade building capacities in the national health systems of weak states.

The contribution is structured as follows: We first emphasize the international duty to cooperate, particularly in the context of norm collisions. We then reflect on the opportunities of multi-level cooperation during a global health crisis and discuss the challenges, in particular sustainability concerns, related to this.

\section{The Duty to Cooperate and Norm Collisions}

Following the rapid and massive spread of COVID-19, we could observe different scenarios when it comes to cooperation. Nation states were forced to make decisions protecting the citizens of their own territory. This led to some countries neglecting opportunities to cooperate or even refusing to cooperate. With the closing of borders, flight bans, discrimination against 
Asian (and other) nationals, the Trump administration's attempts to move research of the firm CureVac on a COVID-19 vaccine from Germany to the USA or its decision to discontinue funding the World Health Organization (WHO), we could witness alarming tendencies towards nationalism (Vogel 2020). In other cases, states with strong capacities, additional expertise and resources also fostered cooperation. Examples are doctors from Cuba helping in Italian hospitals, French patients being treated in German clinics, and China exporting protective equipment.

Global challenges, such as the climate crisis, have taught us that complex transnational problems like these cannot be addressed with isolated or nationalist responses. Yet, recent debates have focused relatively little on the duty to cooperate in implementing the right to health, despite its codification in the International Covenant on Economic, Social and Cultural Rights (ICESCR) and other targeted treaties, such as the Convention on the Rights of the Child (CRC) (Mair 2012, 3).

This means member states with respective resources have a duty to assist less capable states, and in particular their vulnerable citizens, to achieve "the highest attainable standard of health" and in "the prevention, treatment and control of epidemic [...] and other diseases" (ICESCR 1966, Art. 12). In human rights scholarship, the duty to cooperate and corresponding transboundary obligations, known as extraterritorial state obligations, are increasingly discussed in relation to private business responsibilities and climate change. These debates are certainly relevant in the context of COVID-19 as well.

Amidst a number of complex scenarios and difficult political decisions state governments have to take during the pandemic, guaranteeing the right to health has been a normative priority. The policy measures taken, in most cases a national lockdown or even a curfew, can lead to a norm conflict between different human rights (Milanovic 2009). This means the protection of one human right can put the realization of another right at risk. There are a number of examples illustrating this collision of human rights: To protect the right to life and provide for the right to health, citizens can be prohibited to meet in a group, which means their right to practice their religion, their right to education or their right to assembly and association is limited. With the closing of borders in Europe, for instance, and restrictions on leaving the house, like in Spain or Italy, people's freedom of movement is affected. Even though we can observe protests against these measures all over the world, these are legitimate forms of temporarily suspending human rights in times of emergency known as derogation. 
There are two aspects worth paying closer attention to when analyzing these human rights collisions. First, policy responses to COVID-19 have exacerbated already existing inequalities among vulnerable groups whose rights are even more affected. Children from poorer social backgrounds, for instance, have more difficulties in securing access to online learning and the necessary technical equipment or infrastructure, which means that their educational outcomes are even more affected (UNICEF 2020). Also, the health and livelihoods of women are disproportionately affected due to their generally lower incomes and job security, the reallocation of resources away from sexual and reproductive health services, the disproportionate amount of unpaid care work undertaken by women during lockdowns and increased levels of gender-based violence (UN 2020). In many countries, like the UK, women also constitute $80 \%$ of the health and care workers who are particularly exposed to the virus. A UK study further reveals that women's wellbeing dramatically declined and single mothers faced a highly increased risk of depression during the crisis (Zhou et al. 2020). Another example are refugees and asylums seekers who often found themselves trapped in crowded camps with lacking access to accurate information or much needed income opportunities as migration controls became stricter and borders closed (World Economic Forum 2020).

Second, there is an inherent norm conflict in providing for the right to health itself: By attempting to treat citizens infected with coronavirus and by using available hospital capacities, other relevant treatments, including cancer, diabetes and cardio-vascular conditions, were postponed and will lead to increased health problems in the future (The Health Foundation 2020). The number of global excess deaths rose significantly and can, in many cases, be related to delayed access to health care. In many developing countries, restrictions to freedom of movement severely affected access to the right to food and subsistence, again for the most vulnerable groups, causing malnutrition and other indirect health problems. In Uganda, for example, a group of civil society experts has now filed a public interest case to hold the government accountable for not providing adequate access to food for its vulnerable population during the Coronavirus crisis (FIAN 2020).

In this forum article, we argue that some of these inherent norm conflicts and severe consequences for vulnerable groups in developing countries could be mitigated by complying with the duty to cooperate and enabling forms of multi-level cooperation. 


\section{Multi-Level Actor Partnerships}

In earlier research on multi-level actor constellations (MACs), we have identified different forms of cooperative relationships between public and private actors across several governance levels that can - at least temporarily - compensate governmental human rights implementation deficits (Jenichen 2012; Schapper 2014; Jenichen and Schapper 2017; Schapper 2017). MACs usually comprise international organizations, national governments and local civil society partners. Expanding existing research results on transnational advocacy networks (Keck and Sikkink 1998; Price 2003) and public-private partnerships (e.g. Schäferhoff et al. 2009) our analysis has revealed that MACs, in their varying forms, appear primarily in situations in which - due to weak-state capacities - cooperative actor partnerships contribute actively to the implementation of human rights.

We consider our research on multi-level actor partnerships as particularly relevant for realizing the right to health for vulnerable population groups in weak state contexts during the COVID19 crisis. Our research has demonstrated that cooperative partnerships engage directly in the activities that make legal frameworks effective, even in very difficult political conditions and with limited state capacities. MACs are characterized by a clear division of labour and, within a limited time frame during which a norm promoting initiative is implemented, each partner takes over certain responsibilities: IOs, on the basis of their expertise, experience in technical cooperation, material and human resources, often have better access to governments to propose policy initiatives. Governments need to agree that IOs launch a policy initiative within their sovereign territory. Hence, multi-level actor partnerships can only emerge within a cooperative state that has usually ratified the respective human rights instrument and is willing to realize these rights on its national territory but may lack capacities to do so. The government's own role within these partnerships can vary from merely approving a project endeavour to engaging in planning, supervisory and administrative functions or contributing to financial resources, capacity-building and monitoring - depending on its available resources (Jenichen and Schapper 2017). Local actors, finally, contribute their local knowledge and access to local populations. Therefore, they are often contracted to undertake the bulk of tasks related to local human rights implementation. They establish the necessary local infrastructure and institutions, they provide rights-related services, such as health care and education, they engage in awareness-raising and offer income-generating activities (ibid., Schapper 2014; Schapper 2017). They also often make IOs and governments aware of issues on the ground and thus initiate activities (Jenichen 2012). 
This means local actors are crucial in this process: They are the key partners that have access to the actual norm targets and rights-holders, and they know their specific situation, culture, traditions, and context-specific problems. Because of their proximity to local target groups, they can also act as a mediator in managing norm-conflicts. If communities, during the COVID-19 crisis for instance, still come together to practice cultural rituals or their religion, local actors can raise their awareness on keeping social distance to protect the right to health. Or if national lockdown policies threaten the livelihoods of community rights-holders, local partners can deliver food aid. Previous research has demonstrated that norm targets at the grassroots level find it easier to accept norm mediation by local actors who are familiar with their communities and respective challenges (Schapper 2014). IOs, therefore, should be responsive to the suggestions of their (potential) local partners. These research results are in line with other studies that highlight the role of local actors as intermediaries engaging in vernacularization processes that connect behavioral standards codified in international law with local realities and practices (Merry 2006), research on norm localization (Acharya 2012; Zimmermann 2017) and recent analyses accentuating the meaning of local community health workers (Hanrieder 2019).

The example of the last two Ebola outbreaks in Sub-Saharan Africa (2014-16 in Sierra Leone, Liberia and Guinea; 2018-20 in two Eastern provinces of the Democratic Republic of Congo) makes clear how important close cooperation with local actors is in a health crisis. A lack of community involvement in the set-up and delivery of response efforts, such as ambulances, treatment centres, safe burials, quarantine efforts and - since available - vaccines, have led to distrust and resistance against interventions, often based on fears and rumours. In the DRC, for example, rumours spread that Ebola was a hoax for exploiting vulnerable communities and that people were used as guinea pigs by NGOs and pharmaceutical companies; people accordingly often avoided going to treatment centres, fled from response teams or even attacked international infrastructure and health workers (Lees and Enria 2019). Close cooperation with and access to local communities is important to build trust and thus detect cases early and swiftly implement intervention measures. People on the ground need to report incidences and be willing to accept offered treatments and vaccination, otherwise the spread of the disease cannot be contained. In Sierra Leone, for example, engaging local communities in the outbreak response and cooperation with the WHO were essential for containing the virus (Osoro 2017).

One significant move in realizing the right to health through multi-level actor partnerships in the current COVID-19 pandemic are efforts coordinated by Gavi, the Vaccine Alliance. 
Comprising partners from international organizations like the WHO, UNICEF and the World Bank Group, private sector foundations, such as the Bill and Melinda Gates Foundation, but also governments, the pharmaceutical industry and civil society organizations from developing countries, Gavi has significant experiences in multi-level collaboration to deliver vaccinations to the most vulnerable populations groups. Gavi, the Coalition for Epidemic Preparedness Innovations (CEPI) and the WHO are currently co-leading COVAX, which can be described as the vaccines pillar of the Access to COVID Tools (ACT) accelerator. One key objective of COVAX will be to ensure equitable access to COVID-19 vaccines once they have been developed and manufactured (Gavi 2020). Collaboration with local partners, such as NGOs, will be crucial in this regard to ensure that life- and livelihood-saving vaccines will be delivered to the most vulnerable population groups.

Summarized, cooperative partnerships between IOs, the national government and local NGOs can combine their strengths to compensate governmental implementation deficits and to build national capacities for human rights implementation in the long run. Local actors take a crucial role in this process because they can address or even mitigate some norm collisions and represent an important bridge to the local population. Multi-level actor partnerships, however, do not come without certain sustainability concerns, which we discuss in the following.

\section{Sustainability Concerns}

Beyond the risk of asymmetrical power relations within these multilevel actor constellations between - formally more powerful - governmental and - often less powerful - local NGOs, our research (Jenichen 2012; Schapper 2014) demonstrated that one of the main weaknesses of multilevel actor constellations is their limited timeframe: "If international partners withdraw their support and local partners lack the resources required to uphold political pressure on decisionmakers and to manage newly created implementation infrastructures on their own, norm implementation processes launched by MACs often come to a standstill” (Jenichen and Schapper 2017, 20). Moreover, service provision - if undertaken by non-state partners - might undermine the capacity-building of states that are already weak and hamper further state engagement (Batley and Mcloughlin 2010, 148-49). There is a significant risk that policy initiatives commenced by multilevel cooperation dissolve as soon as international partners withdraw. Therefore, we argue, it is particularly important that multilevel partnerships do not only address immediate problems, such as handling the pandemic on the ground, but also focus 
on building sustainable local and national capacities that will endure after international partners leave.

The Ebola outbreak in West-Africa was an important reminder of the significance of investment in primary healthcare and public health capacity. Clinics, hospitals, procurement structures, community health workers, qualified field epidemiologists and training provision are important to identify outbreaks early and introduce measures quickly enough to control an outbreak. Despite large investments by the international community for immediate measures to contain Ebola infections, as well as other single-disease interventions (e.g. against malaria or HIV), global support for strengthening national health systems was lacking (Beisel 2014, Harman 2014). Medical facilities in Liberia, Sierra Leone and Guinea were insufficient to deal with the outbreak, while Senegal and Nigeria, for example, with a more developed infrastructure of medical services and doctors were able to quickly contain outbreaks within their countries (Gegout 2015) Without the existence of well-equipped and fully-functioning health systems, it will be difficult to early detect and control outbreaks of diseases, whether they are Ebola, Corona virus or any other disease such as measles.

For the same reasons, developing countries with stronger health care systems are predicted to be able to weather the Covid-19 pandemic better than others. Mauritius, for example, beyond offering free health care to its citizens, has 3.4 hospital beds per 1,000 population. That is more than the UK (2.8) and certainly better than the sub-Sahara African average of 1.2. The country's relatively advanced social protection system, in addition, helps to cushion the economic effects of lockdown measures (Blin 2020). Cuba is another interesting example which, with its advanced healthcare system (free universal healthcare, the world's highest ratio of doctors to population, advanced medical research industry and labs equipped and staffed to run virus tests), helped the country to respond early and effectively to the pandemic (Morris and Kelman 2020).

These examples illustrate how important a working health care system is to address infections from spreading. Therefore, strengthening national health care services, as well as functioning institutions, effective communication structures and national crisis mechanisms, must remain a priority - also in the current pandemic. Even more so, during the Pandemic, capable countries should establish multi-level actor partnerships to immediately support vulnerable groups and strengthen national health care capacities in the long run. 


\section{Reflections in Light of the COVID-19 Crisis}

In our concluding remarks, we would like to present some final reflections on the protection of most vulnerable groups in weak state contexts through meaningful ways of cooperation during the COVID-19 crisis. The pandemic, just like other crises, can be understood as a threat intensifier, which will increase already existing inequalities and injustices. Vulnerable groups in weak state contexts, including women, children, migrants and refugees, disabled people, the elderly and indigenous peoples, will be most severely affected by the impacts of the health crisis, and often have fewer capacities and resources to adapt. At the same time, they cannot rely on a functioning welfare state to provide necessary health care and related social services.

Despite certain trends towards nationalist solutions, such as vaccine nationalism (Bollyky and Bown 2020), states, and especially those that have ratified the ICESCR, need to be reminded of their human rights duty to cooperate. One meaningful way of cooperation is through multilevel actor partnerships, in which IOs, governments and local NGOs combine their respective strengths. These partnerships can, at least temporarily, compensate governmental deficits in providing for the right to health by making use of the technical expertise and financial resources of IOs, and by engaging local actors, often civil society, who address the needs of the rightsholders on the ground. During the current health crisis, these partnerships could also provide a variety of services to mitigate the adverse effects of national lockdown policies.

Local partners take a crucial role in these actor constellations and can act as mediators between IOs, like the WHO, national governments and affected population groups. They can raise awareness on COVID-19, on washing and sanitizing hands, on wearing masks and social distancing, and they can also engage in testing hard-to-reach communities. For those infected, they could set up appropriate local infrastructure, such as clinics and hospitals, and deliver relevant health care services. This infrastructure and all health-related services could progressively be taken over and run by the government - strengthening its so important local and national capacities. At the same time, local partners in multi-level actor constellations could offer necessary rights-related services to alleviate the effects of national lock-down policies for vulnerable groups. These can include food distribution, training on alternative livelihood strategies, or forms of informal education. The latter can alleviate some norm collisions and can prevent inequalities and injustice from further growing. 
For bringing multi-level actor partnerships to life, however, there needs to be increased funding for IOs and during the COVID-19 crisis, in particular, the WHO or initiatives like Gavi and COVAX. Capable states all over the world have the duty to cooperate and to provide assistance to those vulnerable population groups who cannot rely on their own governments to realize the right to health.

\section{References:}

Acharya, Amitav. 2012. Local and Transnational Civil Society as Agents of Norm Diffusion. Paper Presented to the Global Governance Workshop, Department of International Development. Oxford: University of Oxford (1-3 June 2012).

ACLED [Armed Conflict Location and Event Data Project]. 2020. COVID-19 Disorder Tracker. https://acleddata.com/analysis/covid-19-disorder-tracker/. Zugegriffen: 5. August 2020.

Batley, Richard, and Claire Mcloughlin. 2010. Engagement with Non-State Service Providers in Fragile States: Reconciling State-Building and Service Delivery. Development Policy Review 28:131-54.

Beisel, Uli. 2014. Why Ebola wasn't stopped by huge investment in African healthcare. The Conversation, $\quad$ https://theconversation.com/why-ebola-wasnt-stopped-by-hugeinvestment-in-african-healthcare-33114. Zugegriffen: 14. August 2020.

Bollyky, Thomas, and Chad Bown. 2020. The Tragedy of Vaccine Nationalism. Foreign Affairs 99:5, online first.

CDC [Centers for Disease Control and Prevention]. 2020. Health Equity Considerations and Racial and Ethnic Minority Groups. https://www.cdc.gov/coronavirus/2019ncov/community/health-equity/race-ethnicity.html. Zugegriffen: 4. August 2020.

FIAN. 2020. Human Rights Organizations Join Efforts to Defend the Right to Food In Uganda During COVID-19. https://www.fian.org/en/news/article/human-rights-organizationsjoin-efforts-to-defend-the-right-to-food-in-uganda-during-covid-19-2549. Zugegriffen: 13. August 2020.

Gavi. 2020. https://www.gavi.org/covax-facility\#what. Zugegriffen: 14. Oktober 2020.

Ghosh, Jayati. 2020. Modi's Covid-19 policies make clear that in India some lives matter more than others https://www.theguardian.com/commentisfree/2020/jul/29/modis-covid-19policies-make-clear-that-in-india-some-lives-matter-more-thanothers?utm_term =Autofeed\&CMP=twt_gu\&utm_medium\&utm_source=Twitter\#Echo box=1596026869. Zugegriffen: 4. August 2020.

Gegout, Catherine. 2015. Six lessons from the initial failed international response to Ebola. The Conversation, https://theconversation.com/six-lessons-from-the-initial-failedinternational-response-to-ebola-37862. Zugegriffen: 14. August 2020.

Hanrieder, Tine 2019: How Do Professions Globalize? Lessons from the Global South in US Medical Education. International Political Sociology 13:296-314. 
Harding, Andrew. 2020. Coronavirus in South Africa: Why the low fatality rate may be misleading https://www.bbc.co.uk/news/world-africa-53520410. Zugegriffen: 4. August 2020 .

Harman, Sophie. 2014. Ebola crisis in West Africa: where did all the development money go? The Conversation, https://theconversation.com/ebola-crisis-in-west-africa-where-didall-the-development-money-go-31544. Zugegriffen: 14. August 2020.

ICESCR. 1966. International Covenant on Economic, Social and Cultural Rights. http://www.ohchr.org/EN/ProfessionalInterest/Pages/CESCR.aspx. Zugegriffen: 13. August 2020.

Jenichen, Anne. 2012. Politische Innovation in internationalisierten Nachkriegskontexten: Bosnische Frauenrechtspolitik in vergleichender Perspektive. Wiesbaden: VS-Verlag für Sozialwissenschaften.

Jenichen, Anne, and Andrea Schapper. 2017. Between Global Ambitions and Local Change: How Multi-level Cooperation Advances Norm Implementation in Weak State Contexts. Journal of International Relations and Development 20:1-28.

Keck, Margaret E., and Kathryn Sikkink.1998. Activists beyond Borders: Advocacy Networks in International Politics. Ithaca: Cornell University Press.

Lees, Shelley, and Luisa Enria. 2019. Context matters in fighting Ebola: lessons from West Africa for the DRC. The Conversation, https://theconversation.com/context-matters-infighting-ebola-lessons-from-west-africa-for-the-drc-119242. Zugegriffen: 14. August 2020.

Mair, Caroline. 2012. The Maastricht Principles and Environmental Law. London: Foundation for International Environmental Law and Development.

Merry, Sally E. 2006. Human Rights and Gender Violence: Translating International Law into Local Justice. Chicago: Chicago University Press.

Milanovic, Marko. 2009. Norm Conflict in International Law: Whither Human Rights? Duke Journal of Comparative and International Law 20:1-79.

Osoro, Eric. 2017. Ebola virus response: experiences and lessons from Sierra Leone. The Conversation, https://theconversation.com/ebola-virus-response-experiences-andlessons-from-sierra-leone-75931. Zugegriffen: 14. August 2020.

PHE [Public Health England]. 2020. Beyond the Data: Understanding the impact of COVID19

BAME

groups. https://assets.publishing.service.gov.uk/government/uploads/system/uploads/attachment _data/file/892376/COVID_stakeholder_engagement_synthesis_beyond_the_data.pdf. Zugegriffen: 4. August 2020.

Price, Richard. 2003. Transnational Civil Society and Advocacy in World Politics. World Politics 55:579-606.

Schäferhoff, Marco, Sabine Campe, and Christopher Kaan. 2009. Transnational Public-Private Partnerships in International Relations. Making Sense of Concepts, Research Frameworks and Results. International Studies Review 11:451-474.

Schapper, Andrea. 2014. From the Global to the Local: How International Rights Reach Bangladesh's Children. London and New York: Routledge.

Schapper, Andrea. 2017. Children's Rights Implementation as a Multi-level Governance Process. Human Rights Quarterly 39:104-129. 
Shue, Henry. 2014. Climate Justice: Vulnerability and Protection. Oxford: Oxford University Press.

The Health Foundation. 2020. Cancelled NHS treatment may be storing up greater health problems for the future. https://www.health.org.uk/news-and-comment/news/cancellednhs-treatment-may-be-storing-up-problems-for-the-future. Zugegriffen: 13. August 2020.

Tyagi, Juhi. 2012. Weak States. In The Wiley-Blackwell Encyclopedia of Globalization, ed. George Ritzer, 2213-2216. Chichester: Wiley-Blackwell.

UN. 2020. Policy Brief: The Impact of COVID-19 on Women. https://www.un.org/sites/un2.un.org/files/policy_brief_on_covid_impact_on_women_9 _april_2020.pdf. Zugegriffen: 5. August 2020.

UNICEF. 2020. Unequal access to remote schooling amid COVID-19 threatens to deepen global learning crisis. https://www.unicef.org/press-releases/unequal-access-remoteschooling-amid-covid-19-threatens-deepen-global-learning. Zugegriffen: 15. August 2020.

Vogel, Peter. 2020. Nationalism: the even greater risk of the COVID-19 crisis? https://www.imd.org/research-knowledge/articles/Nationalism-the-even-greater-risk-ofthe-COVID-19-crisis/. Zugegriffen: 13. August 2020.

World Economic Forum. 2020. On World Refugee Day, a look at how COVID-19 is affecting refugees and asylum seekers. https://www.weforum.org/agenda/2020/06/world-refugeeday-refugees-asylum-seekers-coronavirus-covid-19-pandemic-response/. Zugegriffen: 13. August 2020.

Zhou, Muzhi, Ekaterina Hertog, Kamila Kolpashnikova, and Man-Yee Kan. 2020. Gender inequalities: Changes in income, time use and well-being before and during the UK COVID-19 lockdown. https://osf.io/preprints/socarxiv/u8ytc/. Zugegriffen: 13. August 2020.

Zimmermann, Lisbeth. 2017. Global Norms with a Local Face? Rule-of-Law Promotion and Norm Translation. Cambridge: Cambridge University Press. 